\title{
ERRATUM
}

\section{THE ORIGIN OF THE CANCER STEM CELL: CURRENT CONTROVERSIES AND NEW INSIGHTS}

\section{Rolf Bjerkvig, Berit B. Tysnes, Karen S. Aboody, Joseph Najbauer and A. J. A. Terzis}

Nature Rev. Cancer 5, 899-904 (2005)

Figure 5 on page 903 of this article was incorrectly printed. The correct full version is shown below.

Mutation

\section{Apoptosis}

(DNA fragmentation)

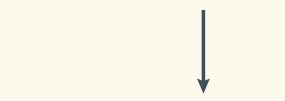

Phagocytosis

(uptake of nuclear

material via

phagosomes)

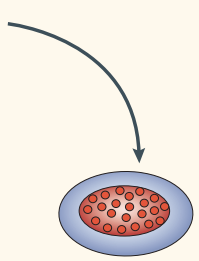

Cell death

Cancer cell

Cancer stem cell 